This article was published as:

Boels, D. (2014). "The challenges of Belgian prostitution markets as legal informal economies: an empirical look behind the scenes at the oldest profession in the world", European Journal on Criminal Policy and Research, Published Online 6 October 2014. DOI 10.1007/s10610-014-9260-8. 


\section{The challenges of Belgian prostitution markets as legal informal economies: an empirical look behind the scenes at the oldest profession in the world}

\section{Introduction}

An extensive body of literature exists on sex work and prostitution, covering a variety of topics which include alcohol and drug use by sex workers (e.g., Decorte, Stoffels, Leuridan, Van Damme and Van Hal 2011), occupational risks for sex workers (e.g., Sanders 2004a), sexual exploitation (e.g., Demir 2010; Van Gestel and Verhoeven 2012), the social ecology of vice districts (Weitzer 2012) and the working conditions of sex workers (e.g., Daalder 2007; van San 2007). Furthermore, several studies have given us more insights into the possible policies towards prostitution and their influence on sex work and sex workers (e.g., Jeffrey and Sullivan 2009; Kavemann 2007; Sanders 2004b; 2008; Scoular 2010; van San 2009). The relation between prostitution and the informal economy, however, has been, as noted by Peršak $(2013)^{1}$, less widely studied. As argued by Ponsaers, Shapland and Williams $(2008,645)$, the informal economy can be described as "the reverse side of the official economy, the boundary between which is drawn by legislation and regulation". In this context, the informal economy comprises all economic activities that are not officially regulated and registered (Adriaenssens et al. 2009; Chen, Jhabvala and Lund 2001; Dell'Anno 2003; Dobovsek 2009; Henry and Sills 2006; Lippens and Ponsaers 2006; Slot 2010) and ultimately, therefore, taxed (Ponsaers 2013). As a result, enforcement of regulation (focused on compliance) has an important role in determining the boundaries between formality and informality. According to this definition, all nonregulated, non-registered and non-taxed prostitution forms part of the informal economy (for more detail see Peršak 2013). For the purposes of this article, prostitution is defined as making oneself available for the performance of sexual acts with another person for remuneration (see Daalder 2007, $21)^{2}$.

The present article aims to contribute to this under-researched domain. Additionally, it aims to feed the policy debate with empirical results. As contended by Huisman and Kleemans (2014), the everrecurring debate on the legalization of prostitution is partly flawed by a conflation of normative and empirical questions. Also, according to Symons and Gillis (2014), several policy frames lack empirical knowledge regarding women's experiences in prostitution. In this article, we hope to offer some empirical grounding for the policy discussion by reflecting on the perceptions of prostitutes and other stakeholders in the prostitution business in Ghent, Belgium ${ }^{3}$. In particular, we offer insights into the relation between prostitution and the informal economy. To these ends, we address the following questions: (1) what are the main characteristics of prostitution in Ghent and (2) how does the existing policy ${ }^{4}$ on prostitution influence the existence of informality in Ghent's prostitution sector? Regarding the first question, we identify the motives of prostitutes for starting in the business, their income, their perceptions of advantages and disadvantages of the work and different types of informal activities related to prostitution.

\footnotetext{
${ }^{1}$ Important exceptions are the works of Sanders (2008) and Verhoeven, van Gestel and Kleemans (2013). The latter have studied the presence and extent of informal economic activities within legalised window prostitution in Amsterdam.

${ }^{2} \mathrm{By}$ using the terms prostitution and prostitute, we aim to make clear what type of sex work we have focused on. However, throughout the article, the terms sex worker and prostitute are used interchangeably.

${ }^{3}$ By focusing on Ghent we also fill in a gap in research on prostitution in Belgium, whose empirical material has previously been drawn from only Antwerp or Brussels (e.g., Loopmans and Van den Broeck 2011; Loopmans and Vermeiren 2009; Van den Hazel et al. 2008; van San 2007; 2009; Weitzer 2012).

${ }^{4}$ For the purposes of this study, policy is considered as the combination of regulation and the enforcement of that regulation.
} 


\section{Data collection}

The empirical results draw on a qualitative research design (Flick 2002) using a combination of document analyses, semi-structured interviews and dossier analyses ${ }^{5}$. In line with previous research (e.g., Sullivan 2010; van den Hazel et al. 2008; van San 2007; Van Wijk et al. 2010), interviews were conducted with both prostitutes (22 interviews) and experts/key informants (i.e., regulators, enforcers and social workers; 16 interviews) active in Ghent ${ }^{6}$. Given the hard-to-reach character of prostitutes (Benoit, Jansson, Millar and Phillips 2005; Decorte et al. 2011; Harcourt and Donovan 2005; Kavemann 2007; Moffatt and Peters 2004), a gatekeeper willing to facilitate access was found ${ }^{7}$ (Agustín 2008; Benoit et al. 2005; Decorte et al. 2011; Kavemann 2007; Sanders 2004b; van San 2007). As this sampling strategy entails a selection bias (van San 2007), we additionally searched for respondents on our own account - by going to windows ${ }^{8}$ and bars $^{9}$ (Van Nunen et al. 2012) - and through snowball sampling ${ }^{10}$ (Atkinson and Flint 2001; Kleemans, Korf and Staring 2008). The sampled prostitutes were of various nationalities ${ }^{11}$ and between them represented all the different prostitution sectors found in Ghent ${ }^{12}$, which is necessary to obtain a view of the diversity of prostitution (van San 2007). The end result of the sampling strategies (purposive and snowball) was a convenience sample, selected on the basis of availability to the researcher (Patton 2002; Decorte et al. 2011; van Nunen, Gryseels and Van Hal 2012). All but three interviews ${ }^{13}$ were fully and anonymously transcribed (Beyens and Tournel 2010) and analysed using MAXQDA 2.

\section{Regulation of prostitution 3.1 National}

In Belgium, prostitution itself has never been penalized (Stevens 2002). In 1948 the then prevailing regulationist discourse (Wetsvoorstel 2013) was exchanged for an abolitionist perspective. From that time, exploitation ${ }^{14}$ of prostitution has been criminalized (Van der Vonder and Van Eynde 1973; Van Loon 2008). Furthermore, local governments were (and still are) authorised to intervene regarding prostitution in order to protect public order and public decency but were forbidden to regulate the conduct of prostitution for other purposes (Loopmans and Van den Broeck 2011). Further changes in the legislation concerning prostitution were implemented in the $1980 \mathrm{~s}$ and $1990 \mathrm{~s}^{15}$ in response to several incidents and the highly influential publication by the investigative journalist De Stoop in 1992. His book exposed in detail the existence of forced prostitution and the trade in women and also the shocking lack of adequate reactions to these phenomena, involving a serious blurring of moral

\footnotetext{
${ }^{5}$ Only four dossiers at the level of the Public Prosecutor could be analysed.

${ }^{6}$ The geographical range of the study is similar to the territory of the local police zone of Ghent.

${ }^{7}$ This sampling strategy lead to 17 interviews. Furthermore, to encourage participation (and as an expression of gratitude) and in keeping with other studies making use of interviews with sex workers (e.g., Agustín 2008; Lever and Dolnick 2010), prostitutes were given a financial reward (of €30).

${ }^{8}$ This term refers to premises where window prostitution takes place.

${ }^{9}$ This strategy lead to four interviews.

${ }^{10}$ This strategy lead to one interview.

${ }^{11}$ Belgian (15, one of Congolese origin), Polish (2), Dutch (1), Hungarian (2) and French (2).

${ }^{12}$ Window prostitution (six women), bar prostitution (five women), private prostitution (six women, of which two also worked as escorts) and escort (one man and four women).

${ }^{13}$ Only three of the 38 interviews were not recorded and thus not fully transcribed.

${ }^{14}$ In the sense of managing/running a prostitution business. In the rest of this article, exploitation refers to managing a prostitution business. The term sexual exploitation will be used to refer to (forced) prostitution in which prostitutes cannot keep their entire earnings.

${ }^{15}$ Among which was the law of 13 April 1995, which contained stipulations concerning the battle against human trafficking and child pornography (Bulletin of Acts, 25 April 1995). Several of its stipulations were amended by the law of 10 August 2005, with the intention of strengthening the battle against human trafficking and human smuggling and against the practices of rack-renters (Bulletin of Acts, 2 September 2005).
} 
standards, corruption on the part of police officers, manifest lack of cooperation and information exchange between enforcers and even rivalry between them (De Stoop 1992). Subsequently, a parliamentary inquiry (Voorstel tot oprichting 1992) resulted in several recommendations (Verslag onderzoekscommissie 1994) and the start of a structural, integral and integrated approach to human trafficking (De Ruyver and Fijnaut 1994). Today, prostitution itself is still not criminalized but several related and ancillary activities such as exploitation of prostitution (art.379 \& $380 \S 1$ penal code), prompting sexual acts in public spaces (art.380bis) and advertising sexual services (art.380ter) are. As a result, the Belgian prostitution market takes the form of a legal informal economy (Sanders 2008) in which facilitators of prostitution are criminalised but prostitutes are not. The actual labour, the act of prostitution, is not regulated and no statute specifically concerning it exists, so that self-employed prostitutes have to declare their earnings under other headings such as 'other personal services' (Acerta 2013; Securex 2013) or 'escort services and the like' (Acerta 2013). In theory, prostitutes cannot work as employees as this would imply an employer exploiting/managing prostitution, which is a criminal offence. In Ghent however, many prostitutes do work as employees, albeit under another term.

\subsection{Local}

As the city of Ghent is confronted with the existence of the exploitation of prostitution, a de facto legalization $^{16}$ (Weitzer 2012, 79) has been opted for regarding this phenomenon. In the 1990s, a notorious gang ${ }^{17}$ held absolute sway over the red-light district (RLD) in that they controlled many prostitution premises, organised trafficking of women and enjoyed the protection of certain members of the local police. Astounded by the discovery of this gang's overwhelming power and the police corruption involved, the mayor at the time commissioned a clean-up of the local police force and an update of the local regulations on (the exploitation of) prostitution. Concerning the former, a unit specialising in human trafficking, prostitution and marriages of convenience (Meprosch-unit) was founded. In the beginning, regulation was purely a police matter. But over time, under the influence of evolutions in the RLD, it has become an increasingly integral approach ${ }^{18}$ in which the tackling of nuisance has an important place.

The point of departure is that publicly accessible establishments where window and bar prostitution take place are considered as cafés and that non-self-employed prostitutes working in these premises are considered as waitresses. As a result, the regulation of the hotel and catering industry (known locally and hereafter as horeca) is applicable to window and bar prostitution (in terms of management and employment) (Van Eeckhoutte 2013), which means that the local police retain some control over these businesses through the granting (or withholding) of liquor licences (Van Gaever and Lameyse 2013). Furthermore, based on a police ordinance ${ }^{19}$ applicable to publicly accessible establishments of consumption and amusement (Stad Gent 2007), managers of windows and bars are obliged to declare

\footnotetext{
${ }^{16}$ This means that prostitution or aspects of it are illegal but nevertheless regulated by the authorities. Weitzer $(2012,79)$ argues that in such systems participants are allowed to operate freely as long as they do not disturb public order or violate other laws and as long as they abide by whatever rules are imposed on them by the authorities.

${ }^{17}$ The Bende van de Miljardair.

${ }^{18}$ In order to tackle feelings of insecurity and nuisance related to prostitution, several city departments and agencies are consulted, stimulated to take preventative measures and/or offer structural solutions for certain kinds of nuisance. In addition, residents and managers of windows are regularly consulted by the city, which takes their concerns and suggestions into account. In this respect, several actors have a role in the outlining of the local policy on prostitution and its related items.

19 Art. 1 Police regulation concerning the obligatory declaration of staff employed in publically accessible establishments of consumption and amusement, approved by the city council of 16 February 1948, altered in the municipal council of 26 March 2007, published on 29 March 2007.
} 
both the commencement and the cessation of employment of their personnel within 48 hours of the event. In this way, prostitutes working in these establishments are registered at the local police. Social workers of the Meprosch-unit invite all new 'waitresses' to a consultation session to inform them of their rights and responsibilities and to collect information on them. As a result of these regulations and practices - and their rigorous application - the local police claim to have a clear picture of managers and prostitutes active in window and bar prostitution (Van Gaever and Lameyse 2013). Additionally, in order to limit infractions of public order, and thus in accordance with the New Municipal Law of $1988^{20}$, the city has imposed specific prostitution-related regulations such as a dress and behavioural code for prostitutes (of which prostitutes are in breach if, for example, they solicit clients by dancing, gestures or tapping on the window).

On the face of it, therefore, the local police ordinances regulate prostitution solely in order to protect public decency and public order, which is in accordance with the legal stipulations (1948 law and the new municipal law). Similarly, by regulating the exploitation of prostitution under a different name (horeca) the city does not, judicially speaking, breach any legal stipulations. From a judicial point of view, regulation falls within the legal framework that determines what cities are allowed to regulate regarding prostitution. Indeed, the city does not judicially regulate the exploitation of prostitution; it is judicially adhering to the regulation of the horeca. However, in practice of course, the city is regulating the exploitation of prostitution. From this point of view, we can conclude that the city is not legally or judicially regulating the exploitation of prostitution, but is regulating it in practice. It is precisely because of this situation (and due to the lack of congruence between regulations, both national and local, and practice) that a grey area between formal and informal economies is created (Ponsaers 2013). Before discussing the nature of this grey area in more detail, we first describe the organisation of Ghent's prostitution sector.

\section{Ghent's prostitution scene 4.1 Types of prostitution}

In contrast to other Belgian cities (van San 2007; Van den Hazel et al. 2008), Ghent does not allow street sex work (Decorte et al. 2011; Porter and Bonilla 2010), its complete prohibition being incorporated into a police ordinance on public order and safety. This seems to be quite effective - most respondents in this study believed that street prostitution is limited. Window prostitution is geographically restricted to the RLD by means of an urban development licensing system. Ghent's RLD has over 40 window prostitution premises dispersed over four streets with 101 windows occupied $24 / 7$ by female prostitutes of more than thirty different nationalities ${ }^{21}$ (Van Gaever and Lameyse 2013). It is located in an area that also hosts regular commerce, schools and residential premises. As in Amsterdam (Huisman and Kleemans 2014), windows are rented for day and night shifts. The rent, known as window money, ranges from $€ 100$ to $€ 150$ per shift. In return, women keep all the money they receive from their clients. Several respondents refer to the 'hardening' of the RLD since the last few years. This hardening is perceived to entail an increasingly fast turnover of sex workers, an increase in East-European sex workers ${ }^{22}$, a perceived increase of pimps and a perceived

\footnotetext{
${ }^{20}$ Article 121 of this law allows municipalities to regulate prostitution insofar as the goal is to ensure public decency and public order.

${ }^{21}$ According to local police statistics, in 2013 the most registered nationalities were Hungarian (283), Belgian (91), French (45) and Dutch (43).

${ }^{22}$ Which is confirmed by statistics of the local police. The same perception (i.e., hardening of the RLD as a result of more East-European prostitutes) was also found in Antwerp (Van San 2007).
} 
rush of tourists from northern France ${ }^{23}$, the latter of which is causing many problems regarding infractions of community order (Van Gaever and Lameyse 2013).

Outside the RLD, two subtypes of bar prostitution occur: mixed window/bar prostitution and prostitution in bars or clubs (Decorte et al. 2011; Van Nunen et al. 2012). In bars and clubs the division of earnings from clients between manager and sex worker is predetermined. For sexual services it is mostly 50/50. For champagne, managers retain a fixed amount to cover the purchase of the champagne (the so-called cork $^{24}$ ). In return, managers usually supply beverages and necessities for sexual services (e.g., condoms, oil, tissues). In some bars and clubs internal rules exist concerning the behaviour of sex workers (e.g., getting to work on time) and the time spent drinking champagne with clients (e.g., one piccolo ${ }^{25}$ in 15 minutes).

Private prostitution in Ghent takes on three forms: prostitutes receiving clients at home, prostitutes working in private residences run by a manager and massage salons ${ }^{26}$. Similar to bars and clubs, managers of houses are responsible for supplying material and advertising. Lastly, escort prostitution, where prostitutes offer their sexual services on location, also takes place in Ghent (Boels, Verhage and Bauters 2013). This can be organised by agencies or by individuals (Decorte et al. 2011). As with private prostitution, the exact extent of escort prostitution cannot be determined as prostitutes active in these types are not registered as prostitutes.

\subsection{Sex workers' perceptions regarding sex work}

\subsubsection{Entering the prostitution business: money talks?}

This section focuses on voluntary prostitution, involving women and men who have deliberately chosen to start in the prostitution business, as forced prostitution is discussed below. This 'voluntary' label includes those prostitutes who, as some interviewed experts point out, start with sex work because they see little alternative to achieving their goals. Limited alternatives or not, nearly all interviewed experts claim that the main driving factor in starting as a prostitute is money, which is in line with previous research (Kingston 2014; van Wijk et al. 2010). Of our 22 interviewed sex workers, 16 cited financial reasons as the main reason for starting and six cited non-financial reasons. Eleven of these 16 started with a clear, predetermined goal in mind such as paying off debts, paying for relatives' medical care, having a decent life-style or paying for studies. Five interviewed workers started in prostitution to earn a lot of money but without having a specific goal in mind. What about the non-financial reasons? One woman wanted to work as a prostitute as she already had many bed partners and thought she might as well earn money from it:

'Because a girl who goes to clubs and has sex with a lot of men in cars, people will say she's a hooker. But, she's a hooker with zero money and zero respect. Me now, yes I'm a hooker, but with money and with respect. That's how I see it.' (SW21-bar worker) ${ }^{27}$

\footnotetext{
${ }^{23}$ Given the non-existence of window prostitution in northern France and its relatively small distance from Ghent, Ghent's RLD is very popular with tourists from this region. With the recent criminalisation of clients in France, several respondents feared the popularity of the RLD would increase even more.

${ }^{24}$ The amount varies from bar to bar. In one bar, for instance, a big bottle of champagne is sold at $€ 300$. The worker who drinks the champagne with the client receives $€ 120$. The manager keeps $€ 120$ for herself and the 'cork' is $€ 60$, which covers the purchase of the bottle (including travel costs to the shops etc.).

${ }^{25}$ The contents of approximately two glasses of champagne.

${ }^{26}$ Massage salons were not taken up in our empirical study.

${ }^{27}$ To ensure anonymity, we have coded our respondents. SW stands for Sex Worker. This quote is translated by the author from French.
} 
Other respondents coincidentally entered the prostitution business owing to circumstances ${ }^{28}$ or chose to quit their former job in favour of the prostitution industry. The latter confirms Brents and Sanders' (2010) argument that middle-class women with educated backgrounds also find their way into sex work as it is perceived as profitable and convenient. Furthermore, as argued by some researchers (e.g., Aronowitz 2014; Huisman and Kleemans 2014; Saunders 2005), these stories illustrate that prostitution cannot simply be equated with sex trafficking or forced prostitution.

As prostitution is more often than not partly informal (see infra), these reasons can be coupled to theoretisations for working informally. For most prostitutes, prostitution does not fulfil a survival function. Admittedly, some prostitutes started with prostitution in order to obtain - according to western standards - rather basic needs (e.g., pay medical care), but most earn more than enough to have a decent living. Most prostitutes did not declare their actual working hours or income correctly, in order to avoid paying taxes and thus to retain a higher net income. As such, this is mostly in line with the voluntarist school of thought regarding the informal economy (Chen 2004; Williams and Lansky, 2013). Some sex workers also found the administrative formalities that needed to be complied with a burden, which is in line with the legalist school of thought (Chen 2004; Williams and Lansky, 2013).

In most cases, after the decision to work as a prostitute has been made, a place of employment is to be found. In this process, social contacts play an important role according to sex workers, as do internet advertisements and flyers. Remarkably, although several prostitutes claim their sex work is a temporary means of income, several sex workers and experts testified to the fact that prostitutes easily get used to earnings from sex work. As in other countries (e.g., Edlund and Korn 2002; Moffat and Peters 2004), money plays an important role in prostitution in Ghent. In our study, about a third (six) of the interviewed prostitutes combined their income from sex work with another means of income, either other employment or an allowance (invalidity, debt mediation). For the majority however, sex work is the only means of income.

In the RLD the 'standard' going rate for vaginal and oral sex lasting a quarter of an hour is $€ 50^{29}$. However, since the increase in the number of Hungarian prostitutes, which started in 2011, sexual services (also unprotected) are often offered at lower prices (€20-€40). Evidently, earnings from window workers depend upon the number of clients they have, the sexual acts they perform, the amount of their window money and the amount they possibly have to hand over to a pimp ${ }^{30}$. Although exact prices vary, different bars and clubs have broadly similar prices for clients. These are clearly higher than in the RLD: $€ 100$ for 15 minutes of sexual services, $€ 150$ for half an hour, $€ 200$ for 45 minutes and $€ 300$ for an hour ${ }^{31}$. Two sex workers active in private houses explain that prices charged to clients are lower than in bars: $€ 80$ for 15 minutes of sexual services, $€ 110-€ 120$ for half an hour and $€ 130-€ 150$ for an hour. Here too, sex workers receive half of these amounts. The income from women receiving clients at home is harder to determine because their prices vary more and some of them pay

\footnotetext{
${ }^{28}$ For instance, one woman, having felt socially isolated after stopping her activities as a hairdresser, started as a telephonist for a friend who did sex work, progressed to being a manager in a private house and finally, having noticed she was popular with the clients there, started as a prostitute herself.

${ }^{29}$ As most prostitutes either do not wish to divulge their income or claim not to be able to do so because it varies too much, we mainly provide rates for clients.

${ }^{30}$ One window prostitute, working five days a week, admits to earning between $€ 4,000-€ 5,000$ ('bad' month) and $€ 10,000-€ 15,000$ ('good' month). Similarly, another, working two nights a week, earns $€ 3,000-€ 4,000$ a month.

${ }^{31}$ One has to keep in mind that sex workers receive only half of these amounts, which implies that for 15 minutes, earnings are similar in the RLD to those in bars and clubs (without taking the window money into account).
} 
taxes whereas others do not. The same holds for escorts: prices cited per hour vary between $€ 150$ and $€ 300$.

Earnings from sex work are used for several purposes: daily expenses, the purchase of luxury products (e.g., designer clothes), body care, home improvements, real estate investments in home countries (e.g., Poland) and investments in studies or job opportunities. In this respect, it seems that prostitution should not be seen as solely a survival strategy. It can also serve as an advancement strategy, a stepping stone to a life with better opportunities (Saunders 2005). Our results suggest that this advancement strategy does not necessarily mean that those who pursue it cease prostitution entirely once desired advances have been achieved. All of the interviewed women for whom prostitution has already served such purposes still work as prostitutes. In this respect, they argue their current money from sex work will facilitate future investments.

\subsubsection{Perceived pros and cons of sex work}

Unsurprisingly, these earnings are perceived by nearly all interviewed prostitutes as the biggest advantage of the work. Other positive aspects highlighted by sex workers were the development of self-confidence due to financial independence, learning the value of money, learning from intelligent and interesting clients, gratitude from clients (cited mainly by private and escort prostitutes), experiences offered by clients which sex workers would otherwise not experience (e.g., luxury holidays, fancy restaurants), the possibility of getting ahead in life thanks to the earnings and sexual satisfaction (this last cited by only one worker). In the light of these perceived advantages, it is not surprising that approximately half of the sex workers interviewed professed to like their job.

Of course, in addition to certain advantages of sex work, some drawbacks of the work are experienced as well. First of all, in line with international literature (e.g., Benoit et al. 2005; Brents and Sanders 2010; Kingston 2014), several experts and sex workers point to the fact that there still exists a taboo around sex work, that sex work is stigmatized and argue that many people have a mistaken view of it. As noted by Benoit et al. (2005), in order to avoid this stigmatization, many sex workers try to conceal their work in various ways such as working at a safe distance from their residence or by leading a 'double life'. In addition, several sex workers experience physical risks (e.g., aggressive clients), medical dangers (e.g., liver problems due to drinking, risk of cervical cancer, risk of STDs) and mental burdens (e.g., listening to marital problems of clients, putting on an act towards clients). (See also in this respect Sanders [2004a]). Interestingly, although most of the sex workers interviewed claimed not to be too worried about their physical safety, the majority of them do take some precautions, for example refusing certain clients, having a pepper spray, deodorant, lacquer spray or knife to hand, and keeping a lock on the door (escorts). In addition, half of the sex workers illustrated how their personal and social life suffers from their work (e.g., relational problems, social isolation).

\subsection{Informality within Ghent's prostitution scene}

As explained above, the city's approach is to partly formalise the exploitation of prostitution. However, this does not rule out the existence of informal activities in the business. These are discussed in this section.

\subsubsection{Partial declaration of labour and income}

As horeca regulation is applicable to window and bar prostitution, women working in these premises are supposed to receive a paid wage based on the hourly horeca rate and their declared working hours. However, regarding the former, we have explained above that women in windows pay window money 
and keep their earnings and women in bars receive a percentage of the client's expenditure ${ }^{32}$. Furthermore, the working hours of prostitutes are usually not declared accurately to the national social security office. A limited number of hours is declared in order to limit labour costs (mainly social security contributions) for both prostitute and employer ${ }^{33}$ (i.e., manager of the bar). In this respect, it is important to note that, according to many experts and sex workers, most (new) foreign sex workers are not aware of this partial declaration. As official payslips are based on the number of declared working hours with (minimum) wages applicable to the horeca, the declared income of prostitutes is less than their actual income. The end result is that the real income of prostitutes is much higher than their declared income, even if employment hours are declared accurately. One Belgian sex worker explains:

'In the RLD? All moonlighters. All of them. Nobody declares her full income. Nobody! Nobody does sex work to declare the full income.' (SW11-escort) ${ }^{34}$

In this respect, the lack of prostitution-specific regulation and the application of horeca regulation enables fraud by resulting in significant untaxed earnings ('black' money) for managers and prostitutes. Although this is perceived by certain prostitutes as an advantage, it also has a downside. Firstly, the social protection of window and bar prostitutes is based on their (limited) officially declared employment and income, which does not result in social protection that is in accordance to their actual labour. Strikingly, several interviewed policymakers somehow reconcile themselves to this state of affairs, as the following quote from an enforcer illustrates:

'So it does not reflect the real situation but it is tolerated in that way by the police, the court and by ourselves in the sense that okay, if at least that is declared, at least that is done. In that way one builds some basic rights' $(\mathrm{EE} 2)^{35}$

A magistrate says:

'We are satisfied, everybody is satisfied with the declaration of the women's performances at the minimum wage. And in fact we hope that they earn more than $€ 8$ an hour, given the type of activity they do. So yes, you could say that nearly all situations of prostitution are informal in one way or another.' (EE7) ${ }^{36}$

Belgian and foreign prostitutes living in Belgium are divided on this matter: whereas some see their sex work as a temporary means of earning a lot of money in a short time span (and thus do not care much about their social security ${ }^{37}$ ), others perceive their sex work more as a real, long term job and therefore acknowledge the need to build up social security rights based on that work. In this respect, a sex worker explains:

'If you work here and there is the horeca, then it's like, later it's also gonna count for your pension I think and everything. You know, I have insurance... So, it's just a normal contract.

\footnotetext{
${ }^{32}$ One interviewed bar worker and one club worker explain a daily fee is paid to the manager (which is also the case in private houses, according to an interviewed private worker) which is used to cover the social security contributions which employers pay for their employees. This fee amounts to approximately $€ 25-€ 30$ a day.

${ }^{33}$ In order to be covered for inspections, many managers make use of documents stating that their employees are exceptionally working outside their contract hours. However, these 'control documents' are often thrown away when no inspections take place. Some managers also de-declare employment of prostitutes retroactively.

${ }^{34}$ This quote is translated by the author from Dutch.

${ }^{35}$ This quote is translated by the author from Dutch.

${ }^{36}$ Idem.

${ }^{37}$ Other prostitutes have other means of income (e.g., other work) on the basis of which their social security is built and thus do not see the point of declaring their prostitution activities.
} 
You get everything. So this is good because when you live here it is good to have insurance if we have to go to the doctor and things like that. So, this is good.' (SW22-window) ${ }^{38}$

Conversely, a Belgian bar sex worker admits having a 16-hour contract but working far more than that in the bar. Concerning the importance of a correct employment contract she says:

'If it's a normal job, yes. But here I don't attach great importance to it because it's a profession in which you easily earn a lot of money and in which you can say you'll stay for only three months for instance. And a 16-hour contract? Oh well, for those three months that's not important to me. If it's a long term job that can last for three years instead of three months, than I need a good contract.' (SW19-bar) ${ }^{39}$

Secondly, as some agreements (e.g., bank loan, tenancy agreement) require proof of a high enough income (payslip), problems can arise when prostitutes apply for such agreements. As most foreign prostitutes (especially the ones who do not live permanently in Belgium) are attracted by quick and high earnings, most respondents argue that these disadvantages do not outweigh their black earnings. However, one Belgian window workers says the following about untaxed earnings:

'It's a ridiculous system. They know we earn a lot of money and we cannot do anything with our money. We cannot buy a house, we cannot buy anything. The only thing we can buy with our untaxed money is luxury.' (SW6-window) ${ }^{40}$

A similar modus operandi is used in private houses, where employment and income are only partially declared $^{41}$ :

'Our work is declared some days, but not all days hey. We have to pay our own social security contributions, $€ 30$ per day that our work is declared. So yes, if you are declared six days out of seven, that is eum $€ 200$ a week. Yeah, some days there is no work, other days you're up to your ears in work. So yeah, anyhow you have to pay those $€ 30$. And furthermore, declaration of work implies way higher costs for the boss and all, so yeah.' (SW13-private) ${ }^{42}$

Three of the interviewed self-employed prostitutes (private and escort) acknowledged not declaring their prostitution activities at all (for varying reasons such as receiving an allowance). Five others claimed to work semi-formally in that they have all the necessary documents to work as self-employed but do not declare their full income from prostitution.

\subsubsection{Pimping}

A general consensus exists among different categories of respondents as to the presence of pimping, which in this article refers to people (pimps) living from the earnings of prostitutes ${ }^{43}$. Especially in the

\footnotetext{
${ }^{38}$ This quote is not translated but reflects the words of the respondent.

${ }^{39}$ This quote is translated by the author from French.

40 This quote is translated by the author from Dutch.

${ }^{41}$ One respondent working in a private house additionally explains how her manager abuses the system of temporary unemployment. This system means that if the employee does not receive his/her wages during the period of unemployment (e.g., for economic reasons) s/he can - under certain conditions - benefit from an unemployment allowance. In this way, an undeserved allowance is combined with earnings from prostitution (as the prostitutes continue working instead of being unemployed).

${ }^{42}$ This quote is translated by the author from Dutch.

${ }^{43}$ Pimping has no legal definition. However, if pimps are prosecuted, this is usually done on the basis of art. 380 , $1^{\circ}, 4^{\circ}$ of the penal code (exploitation of prostitution) or (to a lesser extent) the stipulations concerning human trafficking (art. 433quinquies $\$ 1$ ).
} 
$\mathrm{RLD}^{44}$, many girls are believed to have pimps, which is somehow striking given the frequent presence of the police in the area and their clear view of the RLD (cf., registration of managers and prostitutes, visible concentration of window prostitution). But one magistrate explained how certain characteristics of the RLD (e.g., rapid assessment of the popularity of a girl, few intermediaries, low threshold for clients) still make it an attractive sphere of activity for pimps. Importantly, usually managers of prostitution businesses are not pimps themselves. Our interviews with enforcers and our dossier analyses indicate that pimping also takes place in other types of prostitution, notably escort and bar prostitution.

In line with Demir (2010), several modi operandi for getting women into prostitution are disclosed by our respondents. First, some foreign women are believed to be tricked into prostitution under false promises of a job in, for instance, cleaning or fruit farming. Second, others are believed to realise they will be offered a job in prostitution but not be aware of the working conditions (e.g., handing over earnings, long working hours). The third possibility is the so-called loverboy method (also applied to Belgian victims), in which pimps are believed to deliberately pick out vulnerable women (e.g., young foreign women having a family to support, those living in poor neighbourhoods and/or with limited education) to enhance the chances that they will fall into their trap (see also van San and Bovenkerk 2013).

Once victims are in the hands of pimps, several methods are used to keep them in line. They can be put under pressure to continue working or to obey the pimp by his (threatening to) exercise(ing) physical violence on the victim and her family in the home country. In addition, some girls have been made addicted to drugs and hence need their pimp who also functions as their dealer. Loverboys can also threaten to inform the girl's family about her activities. In line with Harcourt and Donovan's (2005) findings, women can also be forced to work extra shifts when they have not earned enough money. In this context, they often work below the normal price or procure unprotected sexual services in order to obtain the required earnings, which in turn affects business in the RLD generally ${ }^{45}$. This is illustrated by a Polish window worker:

'The problem is that they [Hungarians] do a lot of things for less money. They don't use a condom very often. Maybe I get fewer clients because of that. I open the door and I hear a lot of stupid questions about kissing, sucking without condom, and this kind of thing. It's annoying.'

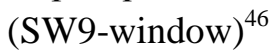

One enforcer explains how pimps do not always need to exert pressure on their victims:

'They're usually unlettered if they come from there [eastern Europe], because they have not finished school. They don't speak the language, they know nothing here. What can they do? Where can they go to? So, they [the pimps] don't have to exert pressure. They just say: "okay, you want to earn money? Fine, go your own way. Ah, but you can't? Fine, I will help you, but then you need to hand me over so much money". That's not real pressure, is it.' (EE5) ${ }^{47}$

\footnotetext{
${ }^{44}$ With regard to the police, this might be partly attributable to the finding that they have less knowledge of private and escort prostitution. In this respect, the dark number is higher for these types of prostitution.

${ }^{45}$ E.g., unfair competition for other prostitutes, spread of sexual transmitted diseases, clients asking for lower prices and unprotected sex. The same has been reported in Antwerp's RLD (Van San 2007).

${ }^{46}$ This quote is not translated but reflects the words of the respondent.

${ }^{47}$ This quote is translated by the author from Dutch. See also van San and Bovenkerk (2013) for more nuanced findings on pimping in Amsterdam's RLD.
} 
In contradiction to the findings of Verhoeven et al. (2013), the window prostitutes interviewed claimed pimps do not sabotage their own work directly (e.g., by demanding protection money or by barring clients from entering). Apart from taking money from them, some respondents attribute a protective role to pimps. However, this is not confirmed by prostitutes working in the RLD:

'Maybe years before, the pimps, when you see they could make something. But now if you see, they all look like clochards and everything you know. They can't do anything... They only come, they only bring them [girls] here and take the money. But I don't think so they protect them. No nono! If you see them, come on! They don't look like they can protect. Maybe if the girl cannot make money, they beat the girl. But to make problems with the clients? I don't think so.' (SW22-RLD) ${ }^{48}$

At the time of writing, victims in Ghent are predominantly East-European (Bulgarian gypsies, Albanian and Hungarian girls). According to some interviewed policymakers, many victims do not consider themselves victims because they (1) share in the luxurious lifestyle of their 'boyfriend', (2) earn more than in their home country, even after handing over (a part of) their earnings ${ }^{49}$, and/or (3) believe they will be permitted to keep their earnings one day. Nevertheless, the window prostitutes interviewed claimed victims are easily identifiable by the long hours they work and the fact that they look sad. Unfortunately, as victims are not often likely to press charges (cf. no perception of victimhood, fear of pimp, fear of police), investigations and prosecution of pimps is hampered. As a result, the continuation of pimping is more the result of enforcement difficulties than the direct result of the local regulatory approach to prostitution. Although legal stipulations are available to tackle pimping, enforcement of these regulatory measures is impeded. In this respect, policy does have an influence on this type of informality in that certain difficulties in proving pimping are partly responsible for the continuation of the phenomenon.

\subsubsection{Ancillary activities and their participants}

In line with previous research on prostitution and informality (Sanders 2008; Verhoeven et al. 2013), several ancillary activities regarding prostitution exist in Ghent: real estate and horeca; shopping services; accounting and advertising. Unfortunately, as a number of investigations were running during the empirical phase of our study, little information on this topic was shared by enforcers for fear of undermining the investigations. In any case, informal participants other than pimps rarely interest the detective enforcers active in prostitution. Furthermore, it is, astonishingly, only in the last three years that the prostitution business has become a domain of interest for the public prosecutor (a specific reason for this could not be given by our respondents). As a result, enforcers have limited knowledge regarding these ancillary activities and its participants.

Real estate managers and owners of windows rent their premises to managers knowing very well the uses to which they will be put, thus facilitating prostitution and its exploitation and earning money from it. The same holds for the manager of the window: he/she receives money for his window, knowing very well this is used to lure clients for prostitution. A manager of a bar has an even more direct income from prostitution: he/she retains about half of the money paid by clients for sexual services and refreshments in the bar. Unsurprisingly, earnings from rents are believed to be only partially declared.

\footnotetext{
${ }^{48}$ This quote is not translated but reflects the words of the respondent. It could be that the men the sex worker refers to in this quote are not the actual pimps but the helpers of the pimps (van San and Bovenkerk 2013).

${ }^{49}$ The amount of money victims have to hand over to their pimps is highly variable.
} 
Near the RLD, some regular cafés are renowned for the presence of pimps. In line with the findings of Verhoeven et al. (2013), these cafés offer the perfect opportunity for pimps to stay close to 'their' prostitutes while they are working. As also found by Verhoeven et al. (2013), shopping boys offer their services to prostitutes in the RLD in exchange for a (small) remuneration. They perform various tasks such as taking laundry to a local launderette, running errands (e.g., getting condoms or cigarettes) or accompanying women home or to their car after their shifts to offer them some protection against potential thieves. Another ancillary activity involves accountants and accounting agencies. They, of course, often perform legitimate tasks such as offering support to bookkeeping. However, three interviewed private and escort prostitutes recounted working (or having worked in the past) with an accountant who determines the amount of income from prostitution that should be declared to the government. Similarly, a bar manager confirms her administrative work is done entirely by her accountant, who, she argues, is an expert in the prostitution business. According to these respondents, the accountants are very well aware of their facilitating role in income tax fraud.

According to art.380ter of the penal code, advertising for prostitution is not allowed. Nevertheless, private sex workers and escorts advertise their services on websites. One Belgian newspaper is infamous for its advertisements for sexual services. A private worker explained how she pays an intermediary in cash who in turn makes sure the newspaper publishes the advertisement. In this way, no official invoices linking the newspaper to sex workers are traceable.

\section{The influence of policy on informality 5.1 Enforcement}

Before discussing the influence of the policy, the way in which the regulation is enforced should be clarified. The trauma of the 1990s (see 3.1 above) still has an influence on the workings of the police. Regarding the local police, only members of the specialised Meprosch-unit are authorised to conduct inspections in Ghent's prostitution premises. The purpose of this restriction is to prevent collaboration between police officers and managers/exploiters ${ }^{50}$. However, it is possible that it could actually facilitate such collaboration because it means that a very limited number of police officers are in regular contact with managers. In order for the unit-members not to build up informal relationships with managers and prostitutes (which was found in the UK by Sanders [2005] and Kingston [2014]) and not to relapse into the mistakes of the past, a thorough control system is needed. It is with this danger in mind that, although the federal police normally focus on phenomena which extend beyond the geographical boundaries of the local police (in which the RLD falls; Van Gaever and Lameyse 2013), they also conduct controls in the RLD on the basis of an informal arrangement between federal and local police:

'Because we consider that a bit as the control of the control. Because if everything were to be done by the local police and the same people were to go to the same places over and over again, it might give occasion for comments in the press or for certain people to abuse that... But it is considered as a way of avoiding overstepping one's bounds as everybody here is still left with the trauma of 'Ze zijn zo lief, meneer ${ }^{51}$ ' in the nineties.' (EE5) $)^{52}$

Notwithstanding this 'control of the control', control mechanisms within the local police could be beneficial (e.g., a rotation system, informing team leaders of each control conducted, thorough screening of new unit members) as the federal police do not monitor the RLD systematically.

\footnotetext{
${ }^{50}$ One exception exists: in cases of emergency calls, members of intervention teams can also enter the premises.

${ }^{51}$ This is the title of De Stoop's book.

52 This quote is translated by the author from Dutch.
} 
Furthermore, the monopoly of the Meprosch-unit implies a limited local police capacity for checking the prostitution sector ${ }^{53}$.

In line with the response to the historical events, human trafficking and sexual exploitation have since 2004 been officially regarded as criminal phenomena needing the prior attention of the police in the four-year national safety plans. Accordingly, prostitution markets receive prior attention in the form of regular administrative and judicial inspections and monitoring from both the Meprosch-unit and the specialised unit of the federal police. Importantly, the Meprosch-unit concentrates on visible prostitution, specifically on the RLD, for several reasons. Evidently, the RLD contains a visible concentration of window prostitution, which is located near the centre of the city. It could also be described as a problem area, given the presence of nuisance and pimps. Concerning the former, research in the UK has equally revealed that police action regarding prostitution markets is related to the presence of nuisance (Kingston 2014). Concerning the latter, a smouldering fear still exists that history will repeat itself. This core attention towards the RLD does not rule out inspections of hidden prostitution (private and escort). Of course, as these types are more difficult to trace (one needs to search advertisements on the internet and in newspapers), preparation of these inspections requires more time and effort.

The prostitution markets receive little attention from other enforcement agencies such as the tax office and social inspectorate services. Social inspectorate services focus on labour relations and on the accurate declaration of employment, and thus do not monitor the self-employed. The agency checking the payment of social security contributions of the self-employed does not specifically focus on prostitutes. Furthermore, according to a magistrate, up until three years before the time of writing, the office of the public prosecutor did not focus on the prostitution sector. This is an astonishing omission in view of the official priority given to human trafficking in the national safety plan (illustrating a lack of continuity between detection and prosecution), but even more astonishing given the city's specific history with sexual exploitation and the huge policy implications of its uncovering (cf. the start of a structural, integral and integrated approach to human trafficking). Currently, exploitation of prostitution is tolerated by the police and public prosecutor insofar as it (1) entails purely the managing of prostitution businesses, (2) does not include serious exploitation of women and (3) does not impact too seriously on community order. By selectively enforcing the regulation concerning exploitation, local authorities partially permit the existence and continuation of an illegal phenomenon (i.e., managing prostitution business). As noted above, several difficulties exist in tackling pimping and sexual exploitation. Nevertheless, two of the window workers interviewed expressed outrage about the obvious presence of pimps in the area, as the following quote illustrates:

'I don't understand why the police do nothing. But I hope they are waiting for the right time? It's also possible. You know, that is, I think it's everywhere, doesn't matter where you are. Mostly there where you have girls who work in prostitution, you also have pimps who are living from the girls. So it's like a symbiosis or something like this. But never in my life, and I'm working quite a long time, I didn't see this so official like I see here in Ghent. They are just walking you know every day and they don't shame themselves, you know.' (SW9-window) ${ }^{54}$

\subsection{The influence of the policy on the choices of workers}

As explained above, the chosen policy on prostitution determines to what extent it forms a part of the informal economy and we have illustrated how the prostitution market in Ghent forms part of a legal

\footnotetext{
${ }^{53}$ The unit consists of eleven police members and two social workers.

${ }^{54}$ This quote is not translated but reflects the exact wordings of the respondent.
} 
informal economy. As prostitution, although legal, is not regulated, it does not exist officially. However, prostitution can be conducted formally under a different term. Our results indicate that most prostitutes work at least partially informally in that employment and income is not accurately declared. As such, informality is 'normal' in the prostitution business. We have seen that financial motives are a driving factor in this practice (e.g., reducing labour costs, increasing net income). As Van Eeckhoutte (2013) points out, prostitutes and managers are able to correctly declare employment and income should they want to. In this respect, the lack of a specific prostitution regulation has no direct influence on this type of informality, which has more to do with a lack of compliance from prostitutes and managers ${ }^{55}$. We agree on this point, but still feel that applying horeca regulation to windows and bars does not stimulate prostitutes and managers to fully declare their employment and income. First of all, it offers several possibilities to facilitate informality (e.g., part-time employment, control documents, low minimum wages). Given the possibility of using control documents and thus to be covered during inspections, it is not surprising some bar managers are not frightened off by the potential for their occurrence. Secondly, the horeca regulation is not adapted to the specific characteristics of the employment (e.g., method of remuneration).

However, we do feel that the limited thorough inspections on correct declaration of employment and income (e.g., fiscal inspections on declaration of income) and the perceived (by our respondents) difficulties in proving untaxed earnings might have more influence on informality than horeca regulation. Window and bar workers have not much to fear from police or inspectorate checks, as fines for undeclared labour target employers, not employees. However, if employees are found to be combining undeclared labour with benefits, they do risk financial setbacks.

Three of the private and escort workers interviewed point to a partial deterrent influence of police inspections. As a result of inspections experienced or the risk of being controlled one day, they have officially registered as self-employed, complying with the resulting administrative requirements. However, they still do not declare their full income from sex work. According to another private worker, the reason for this is that the police do not control the declared income of sex workers:

'They are not the ones checking how much you earn. That's not what they do. In fact, they only check if your paperwork for self-employment is okay. They surely can't sit here with you on a chair and see how many clients you do a day!' (SW1-private) ${ }^{56}$

Most other interviewed sex workers who had experienced police inspections in the past did not fear future police inspections, mainly for the same reason. Furthermore, they did not mention that potential police inspections influenced their choice to partially work informally. Interestingly, most of the interviewed sex workers who had no experience of police inspections did not fear them either.

Checking for the correct declaration of income is the duty of the tax office. However, it does not focus specifically on prostitution markets, which is again striking given the sector's reputation for its undeclared money. It is also clear that the visibility and physical accessibility of windows and bars cannot impede tax inspections. As such, it is not surprising that sex workers' choices for not declaring

\footnotetext{
55 In the Netherlands, since 2008, the fiscal opting-in system can be applied to club, escort and private prostitution (Van Wijk et al. 2010). Although the main aim of the introduction of this condition package (meeting the established criteria is necessary for the application of the opting-in method) was to enhance the position of sex workers (Bijlagemotie Arib 32211, 2011), it was also intended to enhance the fiscal transparency and fiscal compliance of the sector (Taildeman 2010). Currently, researchers are conducting an evaluation of the regulation of legal prostitution in the Netherlands, which should take account of this system. For several reasons however, we doubt that such a system would be effective in Belgium.

56 This quote is translated by the author from Dutch.
} 
their full income was hardly influenced by tax inspections. All in all, we see that inspections of police and inspectorate services (e.g., social inspectorate, tax office) and/or the perceived risk of being inspected one day lead most but not all sex workers and managers to comply with administrative requirements (e.g., control documents, partial declaration of labour hours, registration as selfemployed) but not to fully declare their labour and income. In this way, the enforcement side of the policy partially influences choices of workers regarding their formal and informal work in prostitution.

\section{Perceived pros and cons of the policy}

Apart from its influence on informality, the existing policy in Ghent has both advantages and disadvantages for the different stakeholders. In this article, we focus on the perceptions of sex workers. One sex worker summarizes the Belgian attitude towards ancillary activities very sharply:

'Honestly, I don't understand the whole concept of prostitution in Belgium. It's not allowed ${ }^{57}$. But then there's what you'd call a grey area in which you can do it officially. But it's not allowed. And you can't advertise, you can't recruit clients, you can't put up advertisements but we have afspraakjes.com, we have redlights.be, we have all those sites. We have the paper where we can advertise. But it's not allowed. We have window prostitution areas, but it's not allowed. I mean, just what are we doing? I don't get it. Truly, I honestly don't get it.' (SW17private $)^{58}$

In general, the majority of our interviewed prostitutes are neutral to rather happy with the situation in Ghent, mostly because it offers them relative ${ }^{59}$ anonymity (as employees thanks to horeca contracts and as self-employed due to the lack of specific statute), the possibility of building up social rights if they wish to, the possibility of untaxed earnings (due to slack inspections in this respect) and relative freedom due to the lack of specific regulation (see also Agustín 2008). Nevertheless, some of these prostitutes would favour the introduction of certain rules regarding hygiene standards for prostitution premises and healthcare practices (e.g., mandatory check-ups), the value of which is also argued by some regulators, enforcers and social workers. In this respect, future research could study the feasibility of introducing a self-regulatory system in window, bar and private prostitution regarding hygiene and healthcare, which could take on the form of a quality label (Rijken and van Krimpen 2007). By calling on the sector instead of the government for such regulation, local authorities would not be faced with accusations of falling foul of the legal stipulations ${ }^{60}$ (Vermeulen 2014; Vermeulen and Van Damme 2014). In essence, it could be expected that bonafide segments of the prostitution markets (prostitution premises where sex workers work voluntarily without having to hand over money to some sort of pimp) would adhere to such quality labels, whereas malafide segments (forced, exploitative prostitution) would not (Rijken and van Krimpen 2007). Self-regulation could - when including for instance stipulations to judge the voluntariness of sex workers - furthermore potentially be helpful in more targeted inspections of forced prostitution and sexual exploitation, by leaving more capacity to public enforcers to check segments of prostitution markets that do not adhere to the quality labels. Such future research should include identification of the attitudes of managers on this point (as

\footnotetext{
${ }^{57}$ Note: this perception does not conform to the reality as prostitution is indeed allowed. The quote is translated by the author from Dutch.

${ }^{58}$ This quote is translated by the author from Dutch.

${ }^{59}$ Relative, because horeca contracts and lack of statute do not belie the fact that many prostitutes still have to live a double-life in order for their family, friends and acquaintances not to find out about their profession.

${ }^{60}$ Notwithstanding this fact, Antwerp works with suitability certificates for window prostitution which could be considered as a form of self-regulation (Rijken and van Krimpen 2007). These comprise requirements regarding the premises, applicants for the certificate and managers of the premises. As such, a comparative research between Ghent and Antwerp could shed light on possibilities for Ghent in this respect.
} 
they would be crucial for such a system to be successful), identifying realistic norms and establishing an effective monitoring and sanctioning system. Although this would entail investments from managers (e.g., regarding hygiene standards), adhering to certain norms might have a good return on investment for them by attracting more, classier and/or generous clients. It might also improve relations with local residents and traders (not an economic consideration, but still potentially beneficial). As we have not interviewed managers of windows, we do not know how easy or difficult it is to find prostitutes to occupy the windows, but an upgrading of the RLD could also attract more prostitutes.

A minority of the interviewed prostitutes - mainly private prostitutes - are scandalized by the lack of recognition of prostitution as a profession. In this respect, it is important to note that some of them wrongfully claim not to be able to work legally due to the lack of a statute for prostitution, as the following quote illustrates:

'Now you have the stigma of incorrectness: you're working incorrectly, you're working illegally. But you carry that with you constantly. You can't say okay I chose to work as an escort and I really don't care if you are pro or against that, I chose it. But now you can't say that to anyone. Yeah, it's not done because you're working illegally. Everybody knows it's in the black, nobody can do it officially.' (SW11-escort) ${ }^{61}$

However, most prostitutes insist on the maintenance of their anonymity, both for financial reasons (cf. untaxed earnings) and societal reasons (cf. taboo and stigmatization) and are thus not fully in favour of the regulation of prostitution (especially not of the introduction of a special statute) and its ancillary activities. In this respect, one sex worker has a pronounced opinion:

'If the government deals with us, than we're up shit creek. We'd better try to keep the government out of it. Let it take care of the roads and all that but in Belgian politics we do not need a regulation on prostitution. Hey, we're the ones deciding. Should the government start to... oh... what? They're gonna ask for taxes or what? So for each client that comes, they're gonna say that money is for us? No, no, no! It's not necessary to talk about a regulation. A wellmanaged bar does not need regulation.' (SW21-bar) ${ }^{62}$

More consensus is found among respondents regarding the criminalisation of clients: both experts and prostitutes are clearly not in favour of this option. One prostitute says in this respect:

'It's not possible to make the world better and stop prostitution. If they will make windows euh out, everybody will move to private houses and then yeah... And how you gonna find that then? How will the police find this? Is gonna be more problems because pimps will bring more girls and they will work for less and everything gonna go worse because than this you cannot control at all. So to say that they want to punish people who pay for sex, this is stupid.' (SW22window) $)^{63}$

Most regulators, enforcers and social workers have an ambivalent attitude to the de facto legalization, recognising both its advantages and disadvantages and also its hypocrisy. As a result, some are in favour of the regulation of prostitution and its ancillary activities, as they believe this would enhance the (social and physical) protection of prostitutes, clarify the legal framework in which enforcers operate, increase income for the government and facilitate the detection and eradication of excesses.

\footnotetext{
${ }^{61}$ This quote is translated by the author from Dutch.

${ }^{62}$ This quote is translated by the author from French.

${ }^{63}$ This quote is not translated and reflects the exact wordings of the respondent.
} 
Interestingly, Kingston (2014) found similar reasons offered by police officers and local residents (the majority of whom were in favour of legalization and regulation) in her study of prostitution in the UK. In our study, some respondents, however, feel the time is not yet ripe for prostitution to be put on the political agenda in Belgium. However, with the current policy debates in Europe (e.g., the passing of a non-binding resolution encouraging the criminalisation of clients by the European Parliament), one magistrate thinks Belgium is waiting on policy evaluations in other countries before taking action itself. As sex workers are not organised and represented in politics (e.g., no sex workers' organisations striving for rights, no labour unions defending sex workers' position), their voice is not heard in political debates.

\section{Conclusion and discussion}

This article aims to contribute to the under-researched domain of the relation between prostitution and the informal economy. In this respect, our results point to an influence of both regulation and enforcement on the existence of informal economic activities within Ghent's prostitution sector and on choices workers make in this respect. In addition, although some regulators and enforcers may be highly motivated in their work, the general policy is characterised by a high level of hypocrisy.

Throughout the years following the traumatic events of the 1990s, local regulators and enforcers consolidated their approach to dealing with prostitution markets, an approach that enables them to have a view over the sector. Given the restrictions regarding regulation of prostitution and its exploitation, back doors are used to control the sector. These back doors are not fully adequate for the activities they need to regulate. Although the interviewed police officers are highly motivated to tackle sexual exploitation and pimping, a sort of 'laissez-faire' mentality can be inferred regarding the limited declaration of employment and income. Apparently, many experts are resigned to the situation, as the following quote from a magistrate illustrates:

'Yeah yeah, we can definitely organise a study day on that topic and talk about it all day long, but we're confronted with a reality for which a policy needs to be deployed one way or another and that's just the way it has been done here. Eh, critical questions are always possible, question marks are always possible. We're aware of that.' (EE7) ${ }^{64}$

This resignation appears to be justified by referring to the need to 'establish limited social rights' and the need to 'have a view on the sector'. However, there is an element of hypocrisy and/or insufficiency in both justifications. Notwithstanding the fact that many prostitutes gain a lot in the short term by avoiding taxes and social security contributions, their (limited) social rights are not in balance with the work that they perform. Furthermore, they will not be adequately rewarded at the end of their careers (e.g., in terms of pension) for the hard work they have done. Social security and labour law, the two main tools to ensure the protection of workers, are not sufficiently enforced and thus fail to achieve their goals. Although the fraudulent practices are an open secret, they are maintained by the slack enforcement of social law, which partly results from a lack of political will to intervene in the sector. It is argued by social inspectors interviewed that investigations by social inspectorates into prostitution have a low return on investment (see also Huisman and Kleemans [2014] and Rickles and Ong [2010]). This is mainly attributed to the difficulties of proving undeclared labour, which indicates that social law - which was promoted by the parliamentary inquiry as an important tool in controlling the prostitution sector - comes up against its limits when faced with informality. The auditing of prostitution markets does not yield enough return for the individual social inspector (who is partly

\footnotetext{
${ }^{64}$ This quote is translated by the author from Dutch.
} 
assessed on obtained results) or for the government (re-claimed contributions). But... at least prostitutes have got some basic social rights!

Concerning the second justification, visibility itself is insufficient in tackling undeclared labour and pimping. Admittedly, the difficulties in proving pimping have little to do with the way the de facto legalisation operates (see, for instance, Boels and Ponsaers [2011] on the difficulties of proving human trafficking in Ghent). Nevertheless, the de facto legalisation does not offer enough tools to successfully combat these phenomena. In this respect, one can seriously doubt the influence of the obligation of 'waitresses' to register in combating forced prostitution as they are not required to present themselves in person at the police station - it is only necessary for managers to hand over copies of the women's identity cards. This practice also does little to eradicate illegal employment. All in all, visibility is necessary but insufficient to combat informality. At the time of writing, the city is seriously pondering alternatives for its local regulation of prostitution as it is confronted with many incidents of disorder in the RLD and a residents' association which is putting a lot of pressure on the mayor. As this sector is characterised by a susceptibility to exploitation, this hypocrisy is all the more astounding.

The article has also attempted to contribute to the policy debate on prostitution by offering some insights into the perceptions of prostitutes, who are one of the most important though often forgotten voices in the debate, regarding their work and its policy. Our results indicate prostitution can be opted for voluntarily, both for financial and non-financial reasons. Women starting with prostitution for financial reasons often consider other alternatives, but in the end freely choose prostitution. Of course, this finding does not deny the existence of forced prostitution and sexual exploitation. It furthermore does not mean that prostitutes do not experience difficulties regarding their work. Our empirical results, however, do highlight the fact that prostitution can certainly not, by definition, be equated with violence, exploitation, coercion or male domination, as is done by supporters of the oppression paradigm on prostitution (Symons and Gillis 2014; Weitzer 2012). In this context, it is not surprising that no support was found for the criminalisation of clients, as this view is based on this oppression paradigm. Rather, prostitutes attach importance to building up social rights, anonymity, untaxed earnings, relative freedom, tackling pimping, hygiene and healthcare. The last two of these features are, however, omitted in Ghent's local regulation. Other stakeholders also refer to the need to limit the nuisances related to prostitution.

This empirical study has some limitations. One is the non-random, small sample size (Benoit et al. 2005), which is why we would encourage more and broader empirical research on the perceptions of prostitutes regarding policy on prostitution. Furthermore, some might doubt the validity of taking the words of interviewed sex workers at face value because putting on a show is an essential part of their job. We acknowledge that many prostitutes put on an act, but we do not think this diminishes the value of our research. On the contrary, as we are interested in the subjective perceptions of prostitutes, interviewing them is an essential method (Newburn 2007). How could one learn something about prostitutes' perspectives without including them as respondents? Moreover, we are interested in prostitutes' work-related perceptions, not in their private lives. Exactly this private life is what is kept hidden from people who contact prostitutes in their working roles. Thirdly, (female) researchers are not to be equated with (male) clients as they approach prostitutes for very different goals. Furthermore, prostitutes can benefit from studies highlighting their perceptions of their work and its policy. And if prostitutes prefer to remain silent about their work, they can simply refuse to participate in empirical studies. Lastly, some congruence can be found between the results of this study and the story of an ex-escort agent who came out of the shadows and wrote a popular book about his experiences in the prostitution business (Geets 2013). All in all, several points can answer the 
abovementioned criticisms. We acknowledge that we have not been able to reach prostitutes who admit working with a pimp. However, thanks to triangulation, reliable information on pimping has been found. No systematic statistical data regarding inspections of the prostitution sector could be retrieved at the social inspectorate services. As prostitution is not recognised as a separate economic sector, data are registered under the term 'horeca'. In this respect, the lack of specific data is created by the policy. As a result, the prostitution business remains invisible to policymakers. In an era when inspectors - and by extension enforcement generally - are judged on data (e.g., number of inspections, number of positive results) this invisibility is startling. Fortunately, some compensation can be found from the federal police, who have recently started their own registration method for the prostitution business ${ }^{65}$.

In conclusion, it is necessary to overcome a purely normative attitude to prostitution and look at empirical data to feed the policy debate. Given the varying interests and preferences of different stakeholders (Weitzer 2012), prostitution is notoriously difficult for authorities to manage. Nevertheless, it is important to identify the viewpoints of all stakeholders. Sex workers are often forgotten in empirical research, although they play a key role. Similarly, managers of prostitution premises are not to be neglected either. In this respect, more systematic research should be conducted to make an evidence-based policy possible.

\section{References}

Acerta (2013). Electronic communication, 20 November 2013.

Adriaenssens, S., Van Meeteren, M., Pacolet, J., De Wispelaere, F., Hendrickx, J. andEngbersen, G. (2009). 'De ongekende samenleving: schattingen en inzichten over irreguliere migranten en economische schaduwactiviteiten'. http://hiva.kuleuven.be/resources/pdf/publicaties/R1276.pdf. Accessed 15 March 2011.

Agustín, L. (2008). "Sex and the limits of enlightenment: the irrationality of legal regimes to control prostitution”, Sexuality Research and Social Policy, Vol. 5 (4), 73-86.

Aronowitz., A. (2014). "To punish or not to punish: what works in the regulation of the prostitution market?' in Peršak, N. \&Vermeulen, G. (Eds.), Reframing prostitution: from discourse to description, from moralisation to normalisation (pp.223-251)? Antwerp: Maklu

Atkinson, R. \& Flint, J. (2001). “Accessing hidden and hard-to-reach populations: snowball sampling strategies”, Social Research Update, 33, 1-4.

Benoit, C., Jansson, M., Millar, A. \& Phillips, R. (2005). 'Community-Academic research on hard-toreach population: benefits and challenges', Qualitative Health Research, Vol. 15 (2), 263-282.

Beyens, K. \&Tournel, H. (2010). "Mijnwerkers of ontdekkingsreizigers? Het kwalitatieve interview", in Decorte, T. \&Zaitch, D. (Eds.), Kwalitatieve methoden en technieken in de criminologie (pp. 200232). Leuven: Acco.

Bijlage motie Arib $32211 \mathrm{nr}$. 47: Plan van aanpak versterking sociale positie prostituees, 27 October 2011. www.tweedekamer.nl/kamerstukken/detail.jsp?id=2011D52288\&did=2011D52288 Accessed 1 April 2004.

\footnotetext{
${ }^{65}$ The National Bank of Belgium estimates that the size of drugs and prostitution amounts to $0.6 \%$ of the GDP in Belgium (NBB, 2010).
} 
Boels, D. \& Ponsaers, P. (2011). "Knelpunten in de opsporing en vervolging van mensenhandel en mensensmokkel. Casestudie binnen een gerechtelijk arrondissement", Panopticon, Vol. 32 (5), 33-49.

Boels, D., Verhage, A. \& Bauters, D. (2013). "Prostitutie en informele economie: "met haken en ogen". De paradoxale lokale aanpak van sekswerk". Locomotieftekst Orde van de Dag, december 2013, 6-19.

Brents, B.G. \& Sanders, T. (2010). « Mainstreaming the sex industry : economic inclusion and social ambivalence », Journal of Law and Society, Vol. 37(1), 40-60.

Chen, M.A. (2004). Rethinking the informal economy: linkages with the formal economy and the formal regulatory environment, Paper prepared for the EGDI-WIDER conference, Finland.

Chen, M.A., Jhabvala, R. \& Lund, F. (2001). Supporting workers in the informal economy : a policy framework, Paper prepared for ILO task force on the informal economy. http://previous.wiego.org/papers/policypaper.pdf Accessed 27 February 2014.

Daalder, A.L. (2007). Prostitutie in Nederland na opheffing van het bordeelverbod. Den Haag: WODC. http://www.wodc.nl/onderzoeksdatabase/overkoepelend-rapport-evaluatie-opheffingbordeelverbod.aspx Accessed 5 June 2013.

Decorte, T., Stoffels, I., Leuridan, E., Van Damme, P. \& Van Hal, G. (2011). Middelengebruik onder sekswerkers in België: een kwantitatieve en kwalitatieve studie in vijf sectoren van de seksindustrie, Gent: Academia Press.

Dell'Anno, R. (2003). Estimating the shadow economy in Italy: a structural equation approach. Working paper $N^{\circ} 2003-07$, Department of economics, University of Aarhus, Denmark.

Demir, O.O. (2010). "Dispatches. Methods of sex trafficking: findings of a case study in Turkey", Global Crime, Vol. 11 (3), 314-335.

De Ruyver, B. \& Fijnaut, C. (1994). "De restauratie van het recht van onderzoek? Tevreden experten over de Parlementaire onderzoekscommissie 'Mensenhandel'”, Panopticon, Vol. 2, 101-111.

De Stoop, C. (1992). Ze zijn zo lief meneer. Over vrouwenhandelaars, meisjesballetten en de Bende van de Miljardair. Leuven: Kritak.

Dobovsek, B. (2009). 'The changing problems of the informal economy'. Crimprev paper. http://lodel.irevues.inist.fr/crimprev/index.php?id=220 Accessed 15 March 2011.

Edlund, L. \&Korn, E. (2002). “A theory of prostitution”, Journal of Political Economy, Vol. 110 (1), 181-214.

Flick, U. (2002). An introduction to qualitative research, London/Thousand Oaks/New Delhi: Sage.

Geets, C. (2013). Een pooier vertelt - over escortseks in Vlaanderen, Gent: Borgerhoff\&Lamberigts nv.

Harcourt, C. \& Donovan, B. (2005). "The many faces of sex work", Sexual Transmitted Infections, Vol. 81, 201-206. 
Henry, S. and Sills, S. (2006). 'Informal economic activity: early thinking, conceptual shifts, continuing patterns and persistent issues - a Michigan study', Crime, Law and Social Change, 45, 263-184.

Huisman, W. \&Kleemans, E.R. (2014). "The challenges of fighting sex trafficking in the legalized prostitution market of the Netherlands", Crime, Law and Social Change, DOI 10.1007/s10611-0139512-4.

Jeffrey, L.A. \& Sullivan, B. (2009). "Canadian sex work policy for the $21^{\text {st }}$ century: enhancing rights and safety, lessons from Australia”, Canadian political science review, Vol. 3 (1), 57-76.

Kavemann, B. (2007). The act regulating the legal situation of prostitutes - implementation, impact, current developments. Findings of a study on the impact of the German prostitution act.SoFFI K., Berlin, 43p. http://www.cahrv.uni-osnabrueck.de/reddot/BroschuereProstGenglisch.pdf Accessed 5 June 2013.

Kingston, S. (2014). Prostitution in the community, London/New York: Routledge.

Kleemans, E.R., Korf, D.J. \& Staring, R. (2008). "Mensen van vlees en bloed. Kwalitatief onderzoek in de criminologie", Tijdschrift voor criminologie, 50, 323-336.

Lever, J. \& Dolnick, D. (2010). "Call girls and street prostitutes: selling sex and intimacy", in Weitzer, R. (Ed.), Sex for sale: prostitution, pornography and the sex industry (pp. 187-203). New York: Routledge.

Lippens, R. \& Ponsaers, P. (2006). 'Re-visiting the informal economy: introductory notes', Crime, Law and Social Change, Vol. 45, 259-261.

Loopmans, M. \& Van den Broeck, P. (2011). "Global pressures, localmeasures: the re-regulation of sexwork in the Antwerp Schipperskwartier", Tijdschrift voor Economische en Sociale geografie, Vol. $102(5), 548-561$.

Loopmans, M. \& Vermeiren, K. (2009). "Verborgen prostitutie in Brussel”, Agora, Jaargang 25 (3), 24-25.

Moffatt, P.G. \& Peters, S.A. (2004). "Pricing personal services: an empirical study of earnings in the UK prostitution industry”, Scottish journal of political economy, Vol. 51 (5), 675-690.

NBB (2010). De zwarte economie in de Belgische nationale rekeningen. Cijfers 2007 en evaluatie van de hogere ramingen gesuggereerd door andere studies, Brussel: Nationale Bank van België.

Newburn, T. (2007). Criminology, Cullompton/Portland: Willan Publishing.

Patton, M.Q. (2002). Qualitative research and evaluation methods (3rd edition). London: Sage.

Peršak, N. (2013). "Prostitution in times of economic crisis: effects, human agency and societal responses", in Saitta, P., Shapland, J. \& Verhage, A. (Eds.), Getting by or getting rich? The formal, informal and criminal economy in a globalized world (pp. 305-325). The Hague: Eleven International Publishing. 
Ponsaers, P. (2013). "Illegale of informele economie. Of hoe twee gelijkaardige concepten verschillen van elkaar", Boels, D., Bisschop, L., Kleemans, E. \& van de Vijver, C. (Eds.), Informele en illegale economie (pp. 17-32). Cahiers Politiestudies 29, Antwerpen: Maklu.

Ponsaers, P., Shapland, J. \& Williams, C. (2008). "Does the informal economy link to organized crime?", International Journal of Social Economics, Vol. 35 (9), 644-650.

Porter, J. \& Bonilla, L. (2010). "The ecology of street prostitution", in Weitzer, R. (Ed.), Sex for sale: prostitution, pornography and the sex industry (pp. 163-186). New York: Routledge.

Rickles, \& Ong, (2010). "Effects of wage and hour law enforcement on informal work", in Marcelli, E., Williams, C.C. \& Joassart, P. (Eds.), Informal work in developed countries (pp.153-167). London: Routledge.

Rijken, C. \& van Krimpen, L. (2007). "A pilot study on the development and the feasibility of introducing European quality labels in the prostitution sector in the Netherlands", in Vermeulen, G. (2007), EU quality standards in support of the fight against trafficking in human beings and sexual exploitation of children (pp.205-299), Antwerp: Maklu.

Sanders, T. (2004a). "A continuum of risk? The management of health, physical and emotional risks by female sex workers", Sociology of Health and Illness, Vol. 26 (5), 557-574.

Sanders, T. (2004b). "The risks of street prostitution: punters, police and protesters", Urban Studies, Vol. (41 (9), 1703-1717.

Sanders, T. (2008). "Selling sex in the shadow economy", International Journal of Social Economics, Vol. 35 (10), 704-716.

Saunders, P. (2005). "Traffic violations: determining the meaning of violence in sexual trafficking versus sex work", Journal of Interpersonal Violence, Vol. 20 (3), 343-360.

Scoular, J. (2010). "What's law got to do with it? How and why law matters in the regulation of sex work", Journal of Law and Society, Vol. 37 (1), 12-39.

Securex (2013). Electronic communication, 20 November 2013.

Slot, B.M.J. (2010). 'Informele economie: oorsprong, oorzaak en ontwikkeling', Justitiële Verkenningen, Vol 36 (7), 9-24.

Stad Gent (2007). Politiereglement op de verplichte aangifte van dienstpersoneel tewerkgesteld in voor het publiek toegankelijke inrichtingen van verbruik en vermaak, goedgekeurd in de gemeenteraad van 16 februari 1948, gewijzigd in de gemeenteraad van 26 maart 2007, bekendgemaakt op 29 maart 2007.

http://www.gent.be/docs/Diensten\%20van\%20de\%20Stadssecretaris/Stadssecretariaat/Politiereglemen t_aangifte_dienstpersoneel_inrichtingen_van_verbruik_en_vermaak.pdf Accessed 21 March 2013.

Stevens, L. (2002). Strafrecht en seksualiteit : de misdrijven inzake aanranding van de eerbaarheid, verkrachting, ontucht, prostitutie, seksreclame, zedenschennis en overspel. Antwerpen: Intersentia.

Sullivan, B. (2010). "When (some) prostitution is legal: the impact of law reform on sex work in Australia", Journal of law and society, Vol. 37 (1), 85-104. 
Symons, K. \& Gillis, K. (2014). "Talking about prostitution and the representation of a (problematic) group: identifying frames in Flemish news coverage on prostitution", in Peršak, N. \&Vermeulen, G. (Eds.), Reframing prostitution: from discourse to description, from moralisation to normalisation (pp. 121-143)? Antwerp: Maklu.

Taildeman, I. (2010). Bruikbaarheid van het Nederlandse opting-in model in de Belgische prostitutiesector?Master'sdissertationcriminology. Ghent: Ghent University.

Van den Hazel, R., Lesger, D. Peters, T., van Oijen, S., Loopmans, M., Gabiam, K. \&Kesteloot, C. (2008). Prostitutie Brussel in beeld. Bouwstenen voor een integraal prostitutiebeleid. Arnhem: Seinpost Adviesbureau NV.

Van der Vonder, V. \& Van Eynde, M. (1973). "Het prostitutionele trio: prostituee, souteneur, klant", $R W$ 1973-1974, pp. 625-642.

Van Eeckhoutte, W. (2013). "Seks als beroep: voor werknemers en zelfstandigen. Arbeids-en socialezekerheidsrechtelijke implicaties van de Gentse lokale aanpak van sekswerk", Orde van de Dag (2013/64), 43-48.

Van Gaever, C. \&Lameyse, A. (2013). "Prostitutie in Gent. Het team Meprosch: 'streetcops' in de grijze zone van het prostitutiebeleid", Orde van de Dag, Nr. 64, december 2013, 58-66.

Van Gestel, B. \& Verhoeven, M. (2012). "De organisatie van mensenhandel in een Amsterdamse steeg. Katvangers tegen het licht”, Secondant, 1, 43-44.

Van Loon, T. (2008). Een moraalwetenschappelijke analyse van het Belgisch prostitutiebeleid: 18302007. CEVI Working paper, 2008. http://www.cevi-globalethics.ugent.be/file/14 Accessed 15 April 2013.

Van Nunen, K., Gryseels, C. \& Van Hal, G. (2012). Effectonderzoek naar preventie bij sekswerkers. Antwerpen: Onderzoeksrapport Universiteit Antwerpen.

van San, M. (2007). Schone schijn bedriegt. Over opbloeiende prostitutie in de rafelrand. Rotterdam: Risbo, Rotterdam.

van San, M. (2009). "Verdreven naar de rafelrand", Agora, Jaargang 25 (3), 18-21.

van San, M. \& Bovenkerk, F. (2013). "Secret seducers. True tales of pimps in the red light district of Amsterdam", Crime, Law and Social Change, Vol.60 (1), 67-80.

Van Wijk, A., Nieuwenhuis, A., van Tuyn, D., van Ham, T., Kuppens, J. \& Ferwerda, H. (2010). Samenvatting Kwetsbaar beroep. Een onderzoek naar de prostitutiebranche in Amsterdam. Arnhem: Bureau Beke.

Verhoeven, M., van Gestel, B. \& Kleemans, E. (2013). "Legale sector, informele praktijken. De informele economie van de legale raamprostitutie in Nederland' in Boels, D., Bisschop, L., Kleemans, E. \& van de Vijver, C. (Eds.), Informele en illegale economie (pp. 115-130). Cahiers Politiestudies 29, Antwerpen: Maklu.

Vermeulen, G. (2014). "Self-regulation and public-private cooperation in the prostitution sector", in Peršak, N. \&Vermeulen, G. (Eds.), Reframing prostitution: from discourse to description, from moralisation to normalisation (pp.253-269)? Antwerp: Maklu. 
Vermeulen, G. \& Van Damme, Y. (2014). "Mensenhandel en prostitutie: bestraffing of zelfregulering ter voorkoming van bewust gebruik van gedwongen prostitutie en gedwongen arbeid?", in Pauwels, L. \& Vermeulen, G. (Eds.), Update in de criminologie VII : actuele ontwikkelingen inzake EUjustitiebeleid, cannabisbeleid, misdaad en straf, jongeren en jeugdzorg, internationale vrede, veiligheid en gerechtigheid, gewelddadig extremisme \& private veiligheid en zelfregulering (pp.416440), Antwerpen: Maklu.

Verslag namens de onderzoekscommissie uitgebracht door Mevr. Merckx-Van Goey en Mevr. De T’Serclaes, Parl. St., Kamer 1993-1994, nr. 673/7 - 91/92 (B.Z.), 369p.

Voorstel tot oprichting van een parlementaire onderzoekscommissie belast met het onderzoek naar een structureel beleid met het oog op de bestraffing en de uitroeiing van de mensenhandel, Parl.St., Kamer 1992-1993, nr. 673/4, 91/92 (B.Z.).

Weitzer, R. (2012). Legalizing prostitution. From illicit vice to lawful business.Londen/New York: New York University Press.

Wetsvoorstel (2013). Wetsvoorstel teneinde de strijd tegen seksuele uitbuiting op te voeren, prostitutie te reglementeren en de omstandigheden waarin prostitutie wordt uitgeoefend humaner te maken (ingediend door C. Defraigne). Belgische Senaat, zitting 2012-2013, 5-1960/1.

Williams, C. \& Lansky, M. (2013). "Informal employment in developed and developing economies: perspectives and policy responses”, International Labour Review, Vol. 152 (N³-4), 355-380. 